\title{
Studies on Process Standardization of Probiotic Kulfi by using Encapsulated Modified Psyllium Husk
}

\author{
H. W. Deshpande ${ }^{*}$, S. D. Katke and S. A. S. Hashmi \\ Department of Food Microbiology and Safety, College of Food Technology, VNMKV, \\ Parbhani, Maharashtra, India \\ *Corresponding author
}

\section{A B S T R A C T}

\section{Keywords}

Probiotic kulfi,

Lactobacillus acidophilus,

Lactobacillus bulgaricus,

Psyllium husk,

Lactic acid bacteria,

Encapsulation

Article Info

Accepted:

25 November 2020

Available Online:

10 December 2020
In the present investigation efforts were made for utilization of encapsulated lactic acid bacteria culture (Lactobacillus acidophilus, Lactobacillus bulgaricus) and modified psyllium husk for the preparation of probiotic kulfi. The prepared probiotic kulfi was analyzed for sensorial, physicochemical and microbial quality parameters. Probiotic kulfi was prepared from $1000 \mathrm{ml}$ of milk, $200 \mathrm{gm}$ cream (containing 25 percent fat), $130 \mathrm{gm}$ sugar, 0.5 percent flavour and encapsulated LAB culture having $\left(10^{7}, 10^{8}\right.$ and $10^{9} \mathrm{cfu} / \mathrm{gm}$ containing equal proportions of Lactobacillus acidophilus and Lactobacillus bulgaricus) with 0.65 percent hydrochloric acid modified psyllium husk. The probiotic kulfi was then stored at refrigerated conditions to freezing $\left(-8^{\circ} \mathrm{C}\right.$ to $-10^{\circ} \mathrm{C}$ for $\left.12 \mathrm{hrs}\right)$ and hardening $\left(-18^{\circ} \mathrm{C}\right.$ to $-20^{\circ} \mathrm{C}$ for overnight). The probiotic kulfi was then stored at refrigerated conditions $\left(-18^{\circ} \mathrm{C}\right)$. The organoleptic evaluation of probiotic kulfi was carried out. As per the score of hedonic scale, kulfi with encapsulated 10 percent probiotic culture $\left(10^{9} \mathrm{cfu} / \mathrm{gm}\right)$ with 0.65 percent hydrochloric acid modified psyllium husk had shown maximum consumer acceptability (8.8) among all samples.

\section{Introduction}

Plantago ovata commonly known as 'Psyllium' in English and 'Isabgol' in Hindi belongs to the family of Plantaginaceae, is a $10-45 \mathrm{~cm}$ short-stemmed annual herb known by different names such as ashwagolam, aspaghol, aspagol, blond Psyllium. Isabgol has high fiber content and acts like a sponge serving to clean the bowels and is extensively cultivated in many parts of the globe. It is commercially an important Rabi season crop known for its medicinal properties. Apart from its husk (The seed coat is known as "husk") it is also being used in food industry especially in ice creams, biscuits and candies. The crop is mainly cultivated in the states of Rajasthan, Gujarat, Haryana and Madhya Pradesh.

Notably, India ranks first in Isabgol production (98\%) and is the sole supplier of seeds and husk in the international market. Among medicinal plants, Isabgol is the first 
ranked foreign exchange earner for the country. India is the largest producer and the main supplier of seed and husk to the world market. USA is the chief importer of Isabgol seeds and husk. It contains a significant amount of proteins and husk yields colloidal mucilage which are valued for medicinal application and is used in Ayurveda, unani and allopathic systems of medicines. It is the main constituent of a number of laxative preparations containing sodium bicarbonate and various flavor's used in modern medicine. In India Gujarat and Rajasthan states are the major producer states of psyllium. Psyllium husk is obtained from genus Plantago. The psyllium is high in soluble fiber content with detoxing effect over digestive system makes it a very apt nutraceutical.

The dairy industry is one of the largest industries in India. The exports were made to 105 countries in the world. Dairy production is one of the major sustenance factors for the rural economy of India. At the national level, about 17 percent of the total value of output from agriculture derives from this sector contributing about 8 percent to Gross Domestic Product and placing Indian milk sector in first place (Samal and Pattanaik, 2014). In India about 0.7 percent of the total milk produced is converted into frozen desserts like ice-cream and kulfi.

Kulfi is a frozen dairy product made by suitable blending and processing of Symmetric Multiprocessing (SMP) and other milk products, together with sugar and flavour, with or without stabilizer or colour a typical compositional range for the components used in kulfi mix is milk fat 1016 percent, milk solid not fat 9-12 percent, sucrose 9-12 percent, corn syrup solids 4-6 percent, stabilizers/ emulsifiers $0-0.5$ percent, total solids 36-45 percent, and water 55-64 percent. Kulfi also known as Malai kulfi /Malai-ka-burfi and indigenous frozen dairy product, which closely resembles ice cream in composition. Traditionally kulfi is prepared by evaporating sweetened and flavoured milk by slow heating with almost continuous stirring to keep milk from sticking to the bottom of the vessel until its volume is reduced by a half thus concentrating the milk. It has a distinctive taste due to caramelization of lactose and sugar during the lengthy heating process. It comes in various flavors, including cream, rose, mango, cardamom, saffron (kesar) and pistachio, the more traditional flavors, as well as newer variations like apple, orange, strawberry, peanut, and avocado.

Lactic acid bacteria are the most well-known and widely used probiotic bacteria. The lactic acid bacteria are gram-positive, usually nonmotile, non-sporulating, catalase negative, cocci or rods. They produce lactic acid as a sole product of fermentative metabolism of carbohydrate substrates.

Most lactobacillus species are homo fermentative, producing mainly lactic acid as metabolic by product but some are hetero fermentative i.e., they produce ethanol, $\mathrm{CO} 2$ as well as lactate respectively. Thus, to fulfill the nutritional requirement of probiotic bacteria, prebiotics plays a major role. Probiotics are mainly carbohydrates by nature. According to $\mathrm{FAO} / \mathrm{WHO}$ the definition of prebiotics is, "non digestible substances that provide a beneficial physiological effect on the host by selectively stimulating the favorable growth or activity of a limited number of indigenous bacteria".

Encapsulation is a mechanical or physicochemical process that traps a potentially sensitive material and provide a protective barrier between it and the external conditions. The various encapsulation technique includes extrusion, spray drying, spray cooling, lyophilization, emulsion etc. 
Extrusion is the oldest and most common technique to produce capsule with hydrocolloids. Microencapsulation is the process of encasing an active component in a shell and is defined as a technology of packaging solids, liquids or gaseous materials in miniature, sealed capsules that can release their contents at controlled rates under the influences of specific condition.

From microbiological point of view, microencapsulation can be defined as the process of entrapment, enclosure of cells of microorganisms by means of coating them with proper hydrocolloid(s) in order to isolate the cells from the surrounding environment, in a way that results in appropriate cell release in the intestinal medium. (Jayalalitha 2013).

\section{Materials and Methods}

\section{Procurement of Raw Materials}

Psyllium husk, buffalo milk, fresh cream sugar, cardamom and kulfi moulds were purchased from local market.

\section{Starter culture}

The probiotic organisms viz. Lactobacillus acidophilus and Lactobacillus bulgaricus were individually grown in MRS broth at $37^{\circ} \mathrm{C}$ for $48 \mathrm{hrs}$. The cultivated MRS broth was then centrifuged at $4000 \mathrm{rpm}$ for $10 \mathrm{~min}$ to harvest the cells. The harvested cells were washed twice with sterile water. The biomass was taken as starter culture.

\section{Flow Sheet 1. Preparation of starter culture}

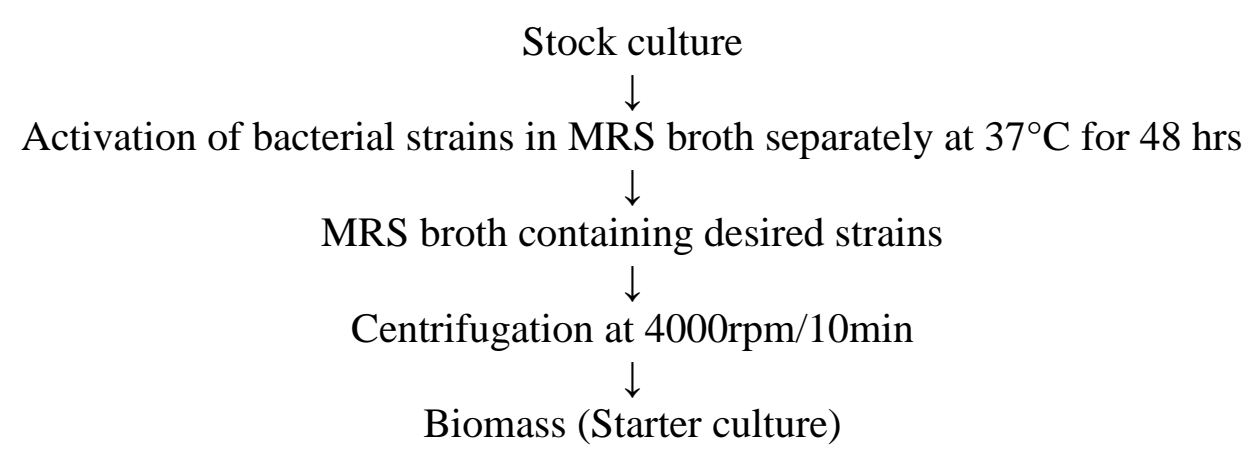

\section{Encapsulation of probiotics}

The microencapsulation of probiotic bacteria was performed using the extrusion technique. Extrusion method is the oldest and most common procedure of producing hydrocolloid capsules (King 1995). It is a simple and cheap method with gentle operations which makes cell injuries minimal and causes relatively high viability of probiotic cells. Biocompatibility and flexibility are some of the other specifications of this method (Klien et al., 1983; Tanaka et al., 1984). Hydrocolloid solution was prepared by using a combination of sodium alginate and guar gum at 1 and 0.8 percent (w/v) respectively, $10 \mathrm{ml}$ of inoculum $(5 \mathrm{ml}$ each of $L$. acidophilus and L. bulgaricus) was mixed in $2 \mathrm{gm}$ of modified psyllium husk powder. Probiotic culture and modified psyllium husk powder normal mixed properly and passed through a syringe in the form of droplets into $0.3 \mathrm{M}$ calcium chloride solution. Interaction between the two solutions led to formations of beads $(2-5 \mathrm{~mm})$ and the resulting beads were then stored in 0.1 per cent peptone (Karthikeyan et al., 2014). 


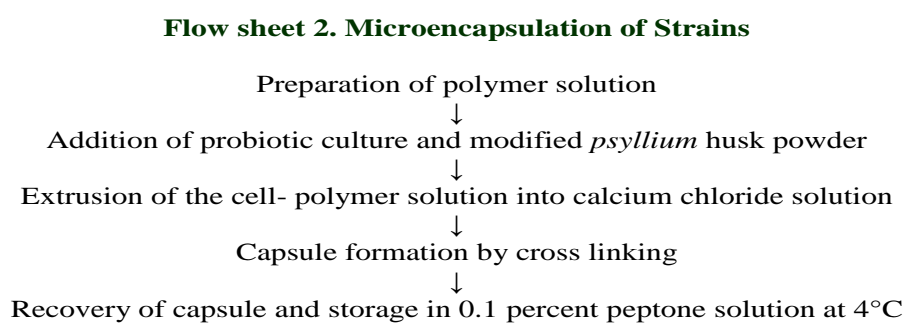

\section{Acid modification of psyllium husk}

Acid modification of psyllium husk was carried out as per the method described by Xiaoyin Pei (2008) with certain changes in concentration of $\mathrm{HCl}$ in ethanol solvent as per the results of the research study conducted by the Syed et al., (2018) on the standardization of acid concentration and solvent ratio for modification of psyllium husk. Hence, acid modification with concentration of 0.65 percent $\mathrm{HCl}$ in the ethanol solvent for solvent ratio of $1.6(\mathrm{w} / \mathrm{v})$.

Solvent ratio was carried out to improve functional properties of psyllium husk as required for exploration in the value addition of processed food products. The solvent used for psyllium husks treatment was vacuum filtered, rinsed with 95 percent ethanol and 100 percent for 2 times each, then dried and stored. Control group was treated with 100 percent ethanol and followed the steps of preparation as in Table 1.

\section{Standardization of probiotic kulfi preparation}

The processing methodology standardized by using organoleptic evaluation. The recipe used for preparation of probiotic kulfi is mentioned below in Table 2.

\section{Preparation of probiotic kulfi}

Buffalo milk blends was taken for the preparation of kulfi. The required quantity of milks having 6 percent fat was taken in a pan and heated at $50^{\circ} \mathrm{C}$ of milk, then added cream by 20 percent and sugar by 13 percent. The stabilizer and flavor were added and well mixed. The flavor at the rate 0.05 percent. The prepared kulfi mix were cooled and poured in filled in moulds. The filled moulds were kept for freezing having about $-8^{\circ} \mathrm{C}$ to $10^{\circ} \mathrm{C}$ at $8 \mathrm{hrs}$ temperature for freezing. It was periodically shaken. After freezing, the moulds were kept in the deep freeze at $-18^{\circ} \mathrm{C}$ to $-20^{\circ} \mathrm{C}$ temperature for overnight for hardening. (Nalkar 2012).

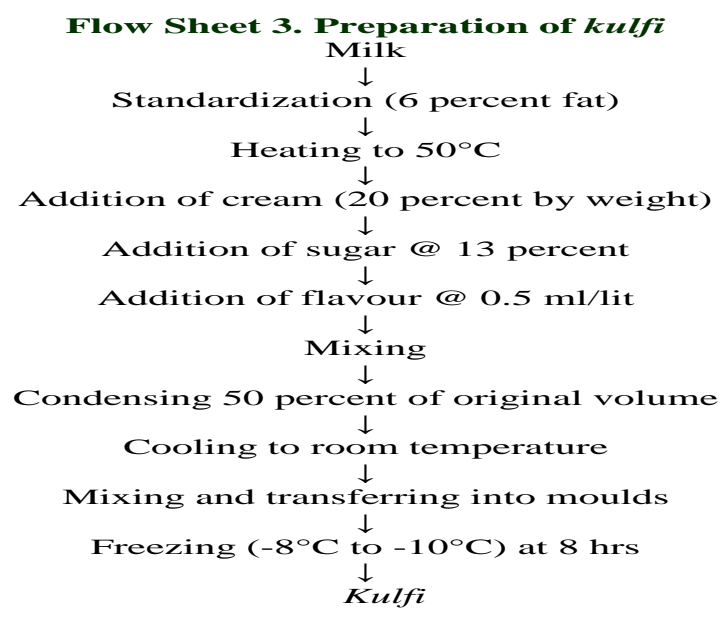




\section{Preparation of probiotic kulfi with encapsulation}

For preparation of probiotic kulfi with encapsulated strains, inoculum at 10 percent of the final kulfi was encapsulated modified psyllium husk with probiotic beads and the beads were aseptically added to $100 \mathrm{gm}$ kulfi. The probiotic kulfi was then stored at refrigerated conditions to hardening $\left(-18^{\circ} \mathrm{C}\right.$ to $-20^{\circ} \mathrm{C}$ for $12 \mathrm{hrs}$ to $24 \mathrm{hrs}$ ).

Flow Sheet 4. Probiotic kulfi with Encapsulation

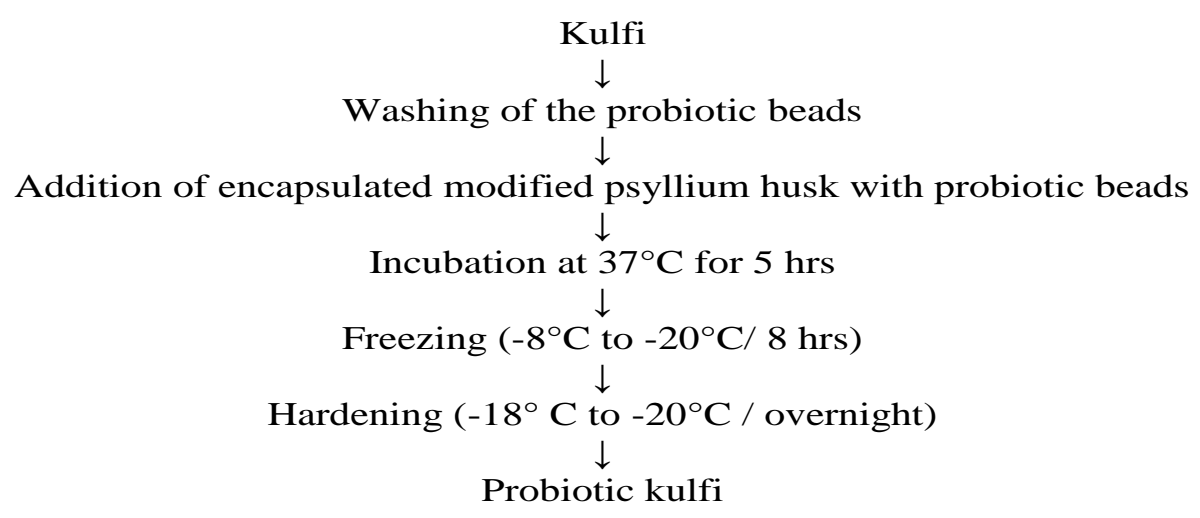

\section{Results and Discussion}

Acid modification of psyllium husk was carried out as per the method described by Xiaoyin Pei (2008) with certain changes in concentration of $\mathrm{HCl}$ in ethanol solvent as per the results of the research study conducted by the Syed et al.(2018) on the standardization of acid concentration and solvent ratio for modification of psyllium husk (Plantago ovata $F$.) i.e. The solvent used for psyllium husks treatment was ethanol with $34-37$ percent hydrochloric acid $(\mathrm{HCl})$ at the concentration level of $0.65 \%$ (w/v). Hence, further studies were conducted to investigate the effects of selected acid solvent ratios at reaction temperature of $37.5^{\circ} \mathrm{C}$ on physical/chemical/functional properties of the acid treated psyllium husk samples. At reaction temperature of $37.5^{\circ} \mathrm{C}$ psyllium husk -solvent ratios (PSH. Solvent @ 1:6 (w/v)) was tested. After the desired time completion of 48hrs for specified acid concentration and PSH and acid solvent ratio. The acid treated psyllium husk product was recovered by vacuum filtration.
It is revealed from the Table 6 that the hydration capacity of psyllium husk was decreased with the acid concentration treatment from 3.0 to $1.6 \mathrm{ml} / \mathrm{g}$. Substantial decrease in hydration capacity was observed in case of PSH sample treated with 0.65 percent acid concentration having lowest 1.6 $\mathrm{ml} / \mathrm{g}$ while control sample having $2.8 \mathrm{ml} / \mathrm{g}$. It can be observed from the Table 6 that the oil absorption capacity of 0.65 percent acid treated psyllium husk for the PSH. solvent ratio @ 1:6 was found to be lowest as $0.5 \mathrm{ml} / \mathrm{g}$, indicating that the OAC of treated psyllium husk decreased with the acid treatment from $1.0 \mathrm{ml} / \mathrm{g}$ (native $\mathrm{PSH}$ ) to 0.5 $\mathrm{ml} / \mathrm{g}$. According to Oladele and Aina (2007), the major chemical component affecting OAC is protein, which is composed of both hydrophilic and hydrophobic parts. Higher OAC might be due to the partial denaturation of proteins with exposition of high hydrophobic proteins which show superior binding to hydrocarbon chains of lipids. The effects of psyllium husk - solvent ratio (1:6) and acid concentration on the water up-taking rate of psyllium samples was also investigated 
at a reaction temperature of $37.5^{\circ} \mathrm{C}$. The data from the Table 6 indicates that the water uptaking rate is lowest for 0.65 percent acid treated psyllium husk for the PSH. solvent ratio@1:6 sample as $1.63 \mathrm{mg} /(\mathrm{g} \times \mathrm{min})$. Moreover, substantial water up-take rate reduction was observed between the raw psyllium husk sample and PSH treated with 0.65 percent acid concentration for PSH. solvent ratio@1:6 as $2.22 \mathrm{mg} /(\mathrm{g} \times \mathrm{min})$ and $1.63 \mathrm{mg} /(\mathrm{g} \times \mathrm{min})$ respectively.

Table.1 Acid treatment levels for psyllium husk

\begin{tabular}{|c|c|}
\hline Concentration of $\mathrm{HCl}$ in Ethanol & Psyllium Husk (PSH). Solvent Ratio \\
\hline $0.65 \%$ & $1.6(\mathrm{w} / \mathrm{v})$ \\
\hline $0 \%$ for Control & $1.6(\mathrm{w} / \mathrm{v})$ \\
\hline
\end{tabular}

Table.2 Standard recipe for preparation of probiotic kulfi

\begin{tabular}{|c|c|}
\hline Ingredients & Quantity $(\mathbf{g} / \mathbf{m l})$ \\
\hline Milk & 1000 \\
\hline Sugar & 130 \\
\hline Cream containing 25 \% fat & $\mathbf{2 0 0}$ \\
\hline Flavor & $\mathbf{0 . 0 5 \%}$ \\
\hline
\end{tabular}

Table.3 Standardization of recipe with different viable counts of cultures

\begin{tabular}{|c|c|c|}
\hline Samples & Inoculum \% & Viable count $(\mathbf{c f u} / \mathbf{g})$ \\
\hline MK & 0 & $\mathbf{0}$ \\
\hline A & 10 & $\mathbf{1 0}^{\mathbf{7}}$ \\
\hline B & 10 & $\mathbf{1 0}^{\mathbf{8}}$ \\
\hline C & $\mathbf{1 0}$ & $\mathbf{1 0}^{\mathbf{9}}$ \\
\hline
\end{tabular}

MK - Milk kulfi without culture addition
A - Kulfi + encapsulated modified psyllium husk with 10 percent probiotic culture having $\left(10^{7}\right) \mathrm{cfu} / \mathrm{gm}$
B - Kulfi + encapsulated modified psyllium husk with 10 percent probiotic culture having
$\left(10^{8}\right) \mathrm{cfu} / \mathrm{gm}$
$\mathrm{C}-$ Kulfi + encapsulated modified psyllium husk with 10 percent probiotic culture having
$\left(10^{9}\right) \mathrm{cfu} / \mathrm{gm}$

Table.4 Quality characteristics of psyllium husk

\begin{tabular}{|c|c|}
\hline Parameters & Results \\
\hline Colour & White or pale buff \\
\hline Appearance & Translucent \\
\hline Taste & Bland Mucilaginous \\
\hline Flavour & Odourless \\
\hline Total ash $(\mathbf{w} / \mathbf{w})$ & $\mathbf{2 . 6 0} \pm \mathbf{0 . 0 3}$ \\
\hline Acid insoluble ash(w/w) & $\mathbf{0 . 2 8} \pm \mathbf{0 . 0 0 4}$ \\
\hline Swell volume(ml/gm) & $\mathbf{4 0 . 5 0}$ \\
\hline Loss on drying(w/w) & $\mathbf{7 . 2 1} \pm \mathbf{0 . 0 2}$ \\
\hline Light extraneous matter $(\mathbf{w} / \mathbf{w})$ & $\mathbf{4 . 9 5} \pm \mathbf{0 . 0 3}$ \\
\hline Heavy extraneous matter $(\mathbf{w} / \mathbf{w})$ & $\mathbf{1} \pm \mathbf{0 . 0 3}$ \\
\hline
\end{tabular}


Table.5 Mineral composition of native psyllium husk

\begin{tabular}{|c|c|}
\hline Parameters & Results $(\mathbf{m g} / \mathbf{1 0 0}$ g) \\
\hline Iron $(\mathbf{F e})$ & $\mathbf{7 . 9 9} \pm \mathbf{0 . 0 1}$ \\
\hline Copper $(\mathbf{C u})$ & $\mathbf{0 . 6 7 2} \pm \mathbf{0 . 0 4}$ \\
\hline Manganese $(\mathbf{M n})$ & $\mathbf{0 . 6 0 0} \pm \mathbf{0 . 0 0 1}$ \\
\hline Zinc $(\mathbf{Z n})$ & $\mathbf{0 . 3 2 2} \pm \mathbf{0 . 0 0 2}$ \\
\hline
\end{tabular}

Table.6 Effect of acid modification on functional properties of psyllium husk

\begin{tabular}{|c|c|c|c|c|}
\hline $\begin{array}{c}\text { Concentration } \\
\text { of HCl in } \\
\text { Ethanol }\end{array}$ & $\begin{array}{c}\text { Psyllium } \\
\text { Husk : } \\
\text { Solvent Ratio }\end{array}$ & $\begin{array}{c}\text { Hydration } \\
\text { capacity } \\
(\mathbf{m l} / \mathbf{g})\end{array}$ & $\begin{array}{c}\text { Oil absorption } \\
\text { capacity }(\mathbf{m l} / \mathbf{g})\end{array}$ & $\begin{array}{c}\text { Water up- } \\
\text { taking rate } \\
(\mathbf{m g} / \mathbf{( g \times m i n}))\end{array}$ \\
\hline Control & $1: 6$ & 2.8 & 0.8 & $\mathbf{1 . 8 8}$ \\
\hline 0.65\% & $1: 6$ & 1.6 & 0.5 & $\mathbf{1 . 6 3}$ \\
\hline $\begin{array}{c}\text { Native Psyllium } \\
\text { Husk }\end{array}$ & -- & $\mathbf{3 . 0}$ & $\mathbf{1 . 0}$ & $\mathbf{2 . 2 2}$ \\
\hline
\end{tabular}

Table.7 Effect of acid modification on proximate composition of psyllium husk

\begin{tabular}{|c|c|c|}
\hline Parameters (\%) & Native psyllium husk & Modified psyllium husk \\
\hline Moisture & 7.15 & $\mathbf{7 . 3 2}$ \\
\hline Fat & 1.82 & $\mathbf{0 . 6 3}$ \\
\hline Protein (N x 6.25) & 2.91 & $\mathbf{1 . 2 0}$ \\
\hline Ash & 2.61 & $\mathbf{2 . 2 3}$ \\
\hline Carbohydrate & 86.48 & $\mathbf{8 8 . 9 5}$ \\
\hline Crude fibre & 3.10 & $\mathbf{2 . 6 5}$ \\
\hline a) Dietary fibre & $75.59 \pm 0.26$ & $\mathbf{7 7 . 6 5} \pm \mathbf{0 . 8 2}$ \\
\hline b) Arabinoxylan & $46.20 \pm 0.21$ & $\mathbf{4 7 . 8 0} \pm \mathbf{0 . 4 8}$ \\
\hline Energy value (Kcal / 100g) & $\mathbf{3 7 1 ~ K c a l / 1 0 0 g}$ & $\mathbf{3 6 6}$ Kcal/100g \\
\hline
\end{tabular}

Table.8 Sensory evaluation of the prepared encapsulated probiotic kulfi

\begin{tabular}{|c|c|c|c|c|c|}
\hline Samples & Colour & Flavour & Taste & Texture & $\begin{array}{c}\text { Overall } \\
\text { acceptability }\end{array}$ \\
\hline MK & 7.8 & 7.6 & 7.6 & 7.5 & $\mathbf{7 . 7}$ \\
\hline A & 8.2 & 7.8 & 7.5 & 7.6 & $\mathbf{7 . 9}$ \\
\hline B & 8.4 & 8.4 & 8.2 & 8.0 & $\mathbf{8 . 3}$ \\
\hline C & $\mathbf{8 . 5}$ & $\mathbf{8 . 8}$ & $\mathbf{8 . 8}$ & $\mathbf{8 . 5}$ & $\mathbf{8 . 8}$ \\
\hline SE \pm & 0.0881 & 0.0816 & 0.1040 & 0.0957 & $\mathbf{0 . 0 9 5 5}$ \\
\hline CD at 5\% & $\mathbf{0 . 2 6 4 0}$ & $\mathbf{0 . 2 4 4 8}$ & $\mathbf{0 . 3 1 1 0}$ & $\mathbf{0 . 2 8 7 1}$ & $\mathbf{0 . 0 2 8 6 2}$ \\
\hline
\end{tabular}


Table.9 Physico-chemical characteristics of probiotic kulfi

\begin{tabular}{|c|c|c|c|c|c|c|c|}
\hline \multirow[t]{2}{*}{ Samples } & \multicolumn{2}{|c|}{$\begin{array}{c}\text { Physical } \\
\text { parameters }\end{array}$} & \multicolumn{5}{|c|}{$\begin{array}{c}\text { Chemical } \\
\text { parameters }\end{array}$} \\
\hline & $\begin{array}{c}\text { Total } \\
\text { Solid\% }\end{array}$ & $\begin{array}{c}\text { Acidity } \\
(\%)\end{array}$ & $\begin{array}{c}\text { Moisture } \\
(\%)\end{array}$ & $\begin{array}{l}\text { Fat } \\
(\%)\end{array}$ & $\begin{array}{c}\text { Protein } \\
(\%)\end{array}$ & $\begin{array}{c}\text { Carbohydrate } \\
(\%)\end{array}$ & $\begin{array}{l}\text { Ash } \\
(\%)\end{array}$ \\
\hline Control & 33.20 & 0.18 & 64.78 & 8.10 & 4.50 & 40.32 & 1.34 \\
\hline Probiotic kulfi & 35.60 & 0.26 & 70.66 & 7.60 & 3.46 & 43.64 & 1.75 \\
\hline
\end{tabular}

Table.10 Effect of probiotic beads on melting time and hardness of probiotic kulfi

\begin{tabular}{|c|c|c|}
\hline Parameters (\%) & Control & Probiotic kulfi \\
\hline Melting time (min) & 35.40 & $\mathbf{3 9 . 0 7}$ \\
\hline Hardness $(\mathbf{m m} / \mathbf{5 s e c})$ & $\mathbf{3 6 . 9 5}$ & $\mathbf{3 8 . 5 0}$ \\
\hline
\end{tabular}

Table.11 Viable counts (LAB) of probiotic kulfi during storage

\begin{tabular}{|c|c|c|c|}
\hline \multirow{2}{*}{ Time in (weeks) } & \multicolumn{3}{|c|}{ Viable counts } \\
\cline { 2 - 4 } & $(\mathbf{c f u} / \mathbf{g m}) \mathbf{1 0} \mathbf{7 0}^{\mathbf{7}}$ & $(\mathbf{c f u} / \mathbf{g m}) \mathbf{X 1 0}$ & $\left.\mathbf{( c f u}^{\mathbf{8}} \mathbf{g m}\right) \mathbf{x 1 0}$ \\
\hline $\mathbf{1}$ & 3.3 & 2.1 & $\mathbf{1 . 5}$ \\
\hline $\mathbf{2}$ & 4.1 & 2.6 & $\mathbf{1 . 9}$ \\
\hline $\mathbf{3}$ & 4.6 & 2.9 & $\mathbf{2 . 1}$ \\
\hline $\mathbf{4}$ & $\mathbf{4 . 9}$ & $\mathbf{3 . 0}$ & $\mathbf{2 . 1}$ \\
\hline
\end{tabular}

Table.12 Microbial quality of Probiotic kulfi during storage

\begin{tabular}{|c|c|c|c|}
\hline $\begin{array}{c}\text { Time in } \\
(\text { weeks })\end{array}$ & $\begin{array}{c}\text { Total Plate Count } \\
(\mathbf{c f u} / \mathbf{g}) \mathbf{1 0}\end{array}$ & $\begin{array}{c}\text { Yeast and Mold } \\
(\mathbf{c f u} / \mathbf{g}) \mathbf{x} 1 \mathbf{4}^{\mathbf{4}}\end{array}$ & Coliform Count \\
\hline $\mathbf{1}$ & 2.30 & ND & ND \\
\hline $\mathbf{2}$ & 2.70 & 1.60 & ND \\
\hline $\mathbf{3}$ & 3.00 & 1.20 & ND \\
\hline $\mathbf{4}$ & $\mathbf{3 . 3 0}$ & $\mathbf{1 . 0 0}$ & ND \\
\hline
\end{tabular}

Fig.1 Sensory Evaluation of prepared encapsulated probiotic kulfi using Hedonic Scale

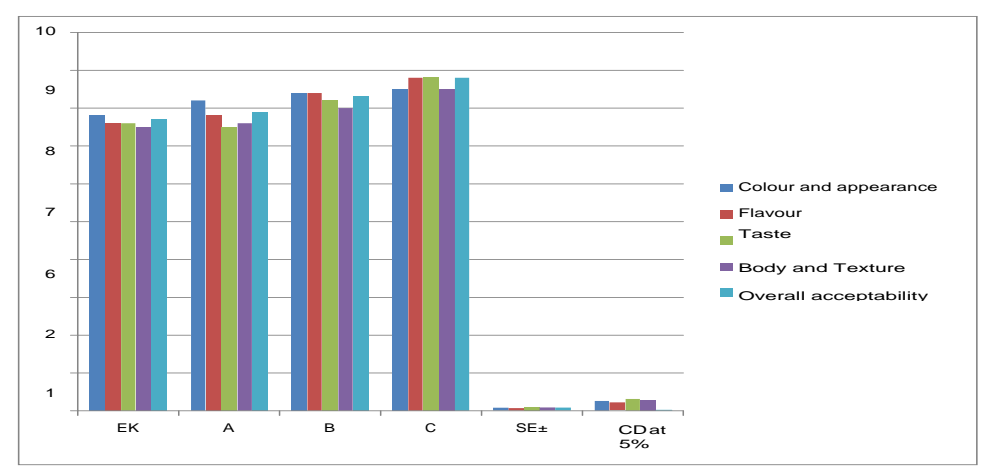


The data for the water up-taking rate showed that acid treatment of PSH at 1:6 @ PSH. solvent ratio highly affects the water uptaking rate, particularly it helps in reduction of water up-taking rate of the psyllium husk. The results for the water up-taking rate are in good agreement with the results found by the Xiaoyin Pei and Liangli $\mathrm{Yu}$ (2008) and Zhihong et al., (2009) for water up-taking rate for acid treated PSH. Similar results were also reported by Syed et al., (2018).

It can be observed from Table 7 that moisture content increased from 7.15 to 7.32 percent upon acid modification. Fat content decreased after acid modification from 1.82 to 0.63 percent while protein content decreased from 2.91 to 1.20 percent. Similarly, ash and crude fibre decreased from 2.61 to 2.23 and 3.10 to 2.65 percent respectively. The decrease in fat, protein, ash and crude fibre content resulted due to the partial degradation of the psyllium gel hardness because of acid modification. Further, carbohydrate content increased from 86.48 to 88.95 percent and energy value decreased from 371 to $366 \mathrm{Kcal} / 100 \mathrm{~g}$. The results are in good agreement with results reported by Syed et al., (2018). The results from the Table 14 also indicates that Dietary fibre and Arabinoxylan contents as $75.59 \pm$ 0.26 and $46.20 \pm 0.21$ percent for native psyllium husk while for acid modified psyllium husk $77.65 \pm 0.82$ and $47.80 \pm 0.48$ percent respectively. The results are in good agreement with results reported by Syed et al., (2018). Slight increase in dietary fibre might be due to marginal increase in the total carbohydrate content resulting from the sugar hydrolysis giving by products such as oligosaccharides, and possibly along with acid salts that may form by reaction of psyllium husk components or other reaction by products as reported by the Liangli $\mathrm{Yu}$ (2000) in the Patent No. WO1999062342 A9. The acid modified psyllium husk degraded on the external surface structure only due to hydrolysis occurred by excursion, that's why dietary fibre did not affected by the acid treatment. Considering psyllium husk as source of dietary fibre some researchers inferred that arabinoxylan as the active fraction helpful to manage various physiological ailments (Fischer et al., 2004; Saghir et al., 2008; Van-Craeyveld et al., 2008). Guo et al., (2008) explored the chemistry of psyllium husk and noted total carbohydrates up to 84.98 percent considering as dietary fibre.

It is evident from the Table 8 that among various sensory characteristics color, flavor and taste were significantly affected by the various levels encapsulated modified psyllium husk with probiotic culture i.e., Lactobacillus acidophilus and Lactobacillus bulgaricus ranging from $10^{7}$ to $10^{9} \mathrm{cfu} / \mathrm{gm}$ and its incubation time period $5 \mathrm{hr}$ and after freezing $\left(-8^{\circ} \mathrm{C}\right.$ to $\left.-20^{\circ} \mathrm{C} / 8 \mathrm{hrs}\right)$.

The observations in respect of acidity of probiotic kulfi as influenced by addition of encapsulated modified psyllium husk with probiotic beads. The acidity content of accepted probiotic kulfi sample were found to be 0.26 percent the acidity of probiotic kulfi remained higher than control. Similarly, the moisture content was 70.66 percent in probiotic kulfi and control samples 64.78 respectively. The fat content was lowest in probiotic kulfi and highest in control sample. It was 7.60 percent in probiotic kulfi samples and 8.10 percent in control samples. The market samples had lower fat content. The protein content was lowest in samples of probiotic kulfi. The protein content of 3.46 percent was, respectively, in control samples 4.50 percent. The results of present study on protein content of market samples as well as in control samples were lower than that of Yarriswamy et al., (1985) but are in fair agreement of PFA (1955) for control samples. The carbohydrate content was lowest in 
control samples 40.32 percent and highest in samples of probiotic kulfi 43.64 percent (Kumar et al., 2012).

The encapsulated modified psyllium husk with probiotic beads on had significant effect on the melting time of the probiotic kulfi samples. The melting time for control was found as $35.40 \mathrm{~min}$ and probiotic kulfi was found as $39.07 \mathrm{~min}$ respectively. This showed that with an increase in the level of probiotic $k u l f i$, there was significant decrease in melting time of control kulfi. This showed improvement in body and texture of kulfi due to beads addition. The control kulfi sample recorded the hardness as 36.95 $\mathrm{mm} / 5 \mathrm{sec}$.whereas probiotic kulfi samples showed hardness as $38.50 \mathrm{~mm} / 5 \mathrm{sec}$ at probiotic beads, it can be observed from the table that with an increase in the level of probiotic beads, there was an increase in the penetration depth values. The results revealed that there was an increase in the penetration depth with an increase in the level of probiotic beads, causing more firmness of the product and presence of large number of viable cells in the treated samples. Shivaprakash (2002) reported that, extent of inoculums has significant effect on hardness of ice cream. Similar observation was made by Salem et al., (2005) and Taha et al., (2007).

A minimum range of $10^{7}-10^{8}$ plate microorganisms per gram or milliliter should be present in food product in order to meet the requirements of a probiotic food, as by the Japanese Fermented Milk and Lactic Acid Bacteria Drinks Association (Ishibashi and Shimanura 1993).

The results from table shows that, the kulfi sample was free from Coliform and E. coli when the sample was fresh and throughout the storage period of 4 weeks at refrigerator temperature $\left(-18^{\circ} \mathrm{C}\right)$ as result of good hygienic and sanitary conditions, during the preparation.

In conclusion probiotic kulfi was prepared from $1000 \mathrm{ml}$ of milk, $200 \mathrm{gm}$ cream (containing 25 percent fat), 130 gm sugar, 0.5 percent flavour and encapsulated LAB culture having $\left(10^{7}, 10^{8}\right.$ and $10^{9} \mathrm{cfu} / \mathrm{gm}$ containing equal proportions of Lactobacillus acidophilus and Lactobacillus bulgaricus) with 0.65 percent hydrochloric acid modified psyllium husk. The probiotic kulfi was then stored at refrigerated conditions to freezing ($8^{\circ} \mathrm{C}$ to $-10^{\circ} \mathrm{C}$ for $\left.12 \mathrm{hrs}\right)$ and hardening $\left(-18^{\circ} \mathrm{C}\right.$ to $-20^{\circ} \mathrm{C}$ for overnight). The probiotic kulfi was then stored at refrigerated conditions ($\left.18^{\circ} \mathrm{C}\right)$. The organoleptic evaluation of probiotic kulfi was carried out. As per the score of hedonic scale, kulfi with encapsulated 10 percent probiotic culture $\left(10^{9} \mathrm{cfu} / \mathrm{gm}\right)$ with 0.65 percent hydrochloric acid modified psyllium husk had shown maximum consumer acceptability (8.8) among all samples.

\section{References}

A.O.A.C. (1990). Official Methods of Analysis. Trends Food Science Technology. Association of Official Analytical Chemists, Washington, DC, USA.

A.O.A.C. (2000). Methods of analysis, 17th ed. Association of official Analytical Chemists, Washington, DC.

A.O.A.C (2003). Official methods of analysis $18^{\text {th }}$ edition, association of official analytical chemists, Washington DC, USA

Chaplin M.F (2003). Fibre and water binding. Proceedings of the Nutrition Society. 62(01), 223-227

Fischer M. H, N. Yu, G. R. Gray, J. Ralph, L. Anderson and J. A. Marlett (2004). The gel-forming polysaccharide of psyllium husk (Plantago ovata Forsk).Carb. Res. 
339:2009-2017.

Guo Q, Cui S.W, Wang Q and Young J.C (2008). Fractionation and physic chemical characterization of psyllium gum.Carbohydrate Pol- ymers. 73(1): 35-43.

Ishibashi $N$ and Shimanura $S$ (1993). Bifidobacteria: research and development in Japan. Journal of Food Technology. 47, 126.

Jayalalitha V (2013). Microencapsulation of probiotics to prepare functional dairy products. Probiotics In Sustainable Food Production: Current Status and Future Prospects Probiotic Foods. 12-21.

Karthikeyan N, Elango A, Kumaresan G, Gopalakrishnamurty T.R and Raghunath B.V (2014). Enhancement of probiotic viability in ice cream by microencapsulation. International Journal of Science Environment and Technology. 3(1):339 -347.

King A. H (1995). Encapsulation of food ingredients: A review of available technology, focusing on hydrocolloids. In: Risch, S. J., Reineccius, G. A., eds. Encapsulation and Controlled Released of Food Ingredient. ACS Sym Ser 590. Washington, DC: American Chemical Society, pp. 26-41.

Klein J, Stock J and Vorlop K.D (1983). Pore size and properties of spherical caalginate biocatalysts. European Journal of Applied Microbiology and Biotechnology. 18:86-91.

Kumar A, Singh K.P, Gupta M.P and Singh B (2012). Indian Research Journal of Extension Education, Special Issue (Volume II).

Nalkar S.D (2012). Preparation of probiotic kulfi with incorporation of mango (mangiferaindica) pulp. ph.d thesis, Department of Animal Husbandry and Dairy Science, Dapoli. 75-76.

Oladele A and Aina J (2007). Chemical composition and functional properties of flour produced from two varieties of tigernut (Cyperus esculentus), African Journal of Biotechnology. 6(21): 24732476.

Samal L and Pattanaik A.K (2014). Dairy production in india -existing scenario and future prospects. International. Journal of Livestock Research. 4(2):105- 113.

Syed KA, Syed HM, Deshpande HW and Sawate AR(2018) Standardization of acid concentration and solvent ratio for modification of psyllium husk (Plantago ovata F.). International Journal of Chemical Studies. 6(2): 2318-2323.

Saghir S, M.S Iqbal, M.A. Hussain, A. Koschella and T. Heinze (2008). Structure characterization and carboxymethylation of arabinoxylan isolated from Ispaghula (Plantago ovata) seed husk. Carbohydrate Polymers. 74:309-317.

Salem M.M.E, Fathi F.A and Awad R.A. (2005).. Production of probiotic ice cream. Polish Journal Food and Nutr. Sci., 14(3): 267-271.

Shivaprakash A (2002). Development of filled probiotic Kulfi. M. Sci. Thesis submitted to University of Agricultural Sciences, Bangalore.

Tanaka H, Masatose $M$ and Veleky I.A (1984). Diffusion characteristics of substrates in calcium-alginate beads. Biotechnology and Bio- engineering. 26: 53-58.

Taha S.H, Abd-EI-Fattah A.M,EI-dairy S.Y, Assous M.T and Attalla N.R (2007). Antioxidant activity of flavoured stirred yoghurt like prod- ucts, Egyptian Journal of dairy Science., 35(1): 31-44.

Van-Craeyveld V.V, J.A Delcour and C.M Courtin (2009). Extractability and chemical and enzymic degradation of psyllium (Plantago ovata Forsk) seed husk arabinoxylans. Food Chemistry. 112:812-819 
Xiaoyin Pei (2008).Acid modification of psyllium. Associate Professor, Liangli (Lucy) Yu, Ph.D, Department of Nutrition and Food Science.

Yu L and Perret J (2003).Effects of solid-state enzyme treatments on the water absorbing and gelling properties of psyllium. Lebensmittel- Wissenschaft and Technologie-Food Science and Technolo- gy. 36(2):203-208.

Yuge Niu, Zhuohong Xie, JunJie Hao, WenBing Yao, Jin Yue, Liangli (Lucy) Yu (2012). Preparation of succinylated derivatives of psyllium and their physicochemical and bile acid-binding properties. Food Chemistry 132: 10251032.

$\mathrm{Yu}$ Liangli (2000).Acid and solvent modification of psyllium. Patentee O1999062342A9.

Zhihong Cheng, Jessica Blackford, Qin Wang, Liangli (Lucy) Yu (2009). Acid treatment to improve psyllium functionality. Journal of Functional Foods, 1(1) January 2009, Pages 44-49.

\section{How to cite this article:}

Deshpande, H. W., S. D. Katke and Hashmi, S. A. S. 2020. Studies on Process Standardization of Probiotic Kulfi by using Encapsulated Modified Psyllium Husk. Int.J.Curr.Microbiol.App.Sci. 9(12): 3452-3463. doi: https://doi.org/10.20546/ijcmas.2020.912.411 